\title{
Zaburzenia metaboliczne i wodno-elektrolitowe u pacjentów z hematologicznymi chorobami nowotworowymi
}

\section{Metabolic and water-electrolyte homeostasis disorders in patients with hematologic malignancies}

\author{
Bożena Katarzyna Budziszewska
}

Klinika Hematologii, Instytut Hematologii i Transfuzjologii, Warszawa

\begin{abstract}
Streszczenie
U pacjentów z nowotworowymi chorobami hematologicznymi zaburzenia metaboliczne $i$ wodno-elektrolitowe występuja zarówno w przebiegu samej choroby, jak $i$ w trakcie prowadzonego intensywnego leczenia przeciwnowotworowego. Do najcześsiej występujacych powiktań metabolicznych i elektrolitowych należa: hiperurykemia $i$ zespót rozpadu guza, hiperamonemia, kwasica metaboliczna, zespót nieadekwatnego wydzielania hormonu antydiuretycznego, hiponatremia, hiperkalcemia, hipokaliemia, zaburzenia gospodarki weglowodanowej. Choroby wspótistniejace, stan ogólny chorego, rodzaj leczenia przyczynowego $i$ wspomagajacego moga sie przyczyniać do zachwiania równowagi metabolicznej chorego. W artykule omówiono najczestsze przyczyny tych zaburzeń, ich objawy $i$ sposób leczenia.
\end{abstract}

Słowa kluczowe: zaburzenia metaboliczne, zaburzenia wodno-elektrolitowe, hematologiczne choroby nowotworowe, leczenie

Hematologia 2018; 9, 1: 22-37

\begin{abstract}
Metabolic and water-electrolyte disorders occur in hematologic malignancies and arise from the disease itself as well as anti-cancer treatment. The most common metabolic and electrolyte complications include: hyperuricemia and tumor lysis syndrome, hyperammonemia, metabolic acidosis, syndrome of inappropriate antidiuretic hormone, hyponatremia, hypercalcemia, hypokalemia and disorders of carbohydrate metabolism. Co-morbidities, performance status of the patient, type of causative and supportive treatment may contribute to disturbing the metabolic balance of the patient. The article discusses the most common causes of these disorders, their symptoms and treatment.
\end{abstract}

Key words: metabolic disorders, water-electrolyte homeostasis disturbances, hematological malignancies, treatment

Hematologia 2018; 9, 1: 22-37

Adres do korespondencji: Bożena Katarzyna Budziszewska, Klinika Hematologii, Instytut Hematologii i Transfuzjologii, Warszawa, ul. Indiry Gandhi 14, 02-776 Warszawa, tel. 2234962 99, faks 22349 63 35, budzisze@poczta.onet.pl 


\section{Wprowadzenie}

Zaburzenia metaboliczne i wodno-elektrolitowe występujące u pacjentów $z$ nowotworowymi chorobami hematologicznymi są związane $z$ biologią, przebiegiem klinicznym choroby i stosowanym leczeniem. Patogeneza tych zaburzeń związanych $z$ obecnością choroby nowotworowej jest złożona i obejmuje: zwiększony obrót komórkowy, apoptozę komórek, kryzy blastyczne, sekrecję hormonów przez komórki nowotworowe, zaburzenia wydzielania cytokin, immunologiczną odpowiedź na obecność nowotworu.

Chemioterapia, radioterapia, steroidoterapia czy zabieg przeszczepienia krwiotwórczych komórek macierzystych mogą prowadzić do zachwiania równowagi metabolicznej ustroju. Skutkuje to pogorszeniem stanu ogólnego pacjenta, a $\mathrm{w}$ konsekwencji - trudnościami w realizacji leczenia przeciwnowotworowego i jego gorszymi wynikami. Powstawaniu zaburzeń metabolicznych i wodno-elektrolitowych sprzyja współistnienie chorób ogólnoustrojowych, takich jak cukrzyca, przewlekła obturacyjna choroba płuc, przewlekła niewydolność krążenia, przewlekła niewydolność nerek czy choroby wątroby $[1,2]$. Czynnikami, które dodatkowo przyczyniają się do wystąpienia tych powikłań, są zaawansowany wiek, kacheksja, sarkopenia, infekcje, niedobory immunologiczne oraz żywienie pozajelitowe $[1,2]$. Do najczęstszych zaburzeń metabolicznych i elektrolitowych $\mathrm{u}$ pacjentów $\mathrm{z}$ chorobami nowotworowymi należą: zaburzenia gospodarki sodowej, potasowej, wapniowej, zespół nieadekwatnego wydzielania hormonu antydiuretycznego (SIADH, syndrome of inappropriate secretion of anti-diuretic hormone), kwasica metaboliczna, hiperurykemia i zespó1 rozpadu guza (TLS, tumor lysis syndrome), hiperamonemia i zaburzenia gospodarki węglowodanowej. Powikłania te pogarszają rokowanie i wyniki leczenia, dlatego istotnym elementem opieki nad pacjentem $z$ hematologiczną chorobą nowotworową jest monitorowanie parametrów równowagi wodno-elektrolitowej i metabolicznej oraz wyrównywanie tych zaburzeń, ponieważ niejednokrotnie prowadzą one do śmiertelnych powikłań.

\section{Zaburzenia gospodarki wodnej}

Woda w organizmie dorosłego człowieka jest rozmieszczona w przestrzeni wewnątrzkomórkowej (PWK; 40\%) i pozakomórkowej (PZK; 20\%), na którą składają się przestrzeń śródnaczyniowa (osocze; 5\%), pozanaczyniowa (15\%) i trzecia przestrzeń (jamy ciała, światło przewodu pokarmowego, przestrzeń podpajęczynówkowa; $2-3 \%$ ). Dzięki dążności ustroju do utrzymywania stałego stężenia jonów (izojonia), w tym również jonów wodorowych (izohydria), ciśnienie osmotyczne płynów ustrojowych wszystkich przestrzeni wodnych jest jednakowe $\left(290 \mathrm{mmol} / \mathrm{kg} \mathrm{mc} . \mathrm{H}_{2} \mathrm{O}\right.$ ) [3-5]. Za utrzymywanie wody w danej przestrzeni odpowiada przede wszystkim stężenie sodu. Inne substancje osmotycznie czynne nabierają znaczenia w przypadku znacznego zwiększenia ich stężenia (mocznik, glukoza) lub niedoboru (białka osocza). Dlatego zmiany całkowitej zawartości sodu w organizmie pociągają za sobą zmiany objętości PZK, a tym samym — objętości całkowitej wody w ustroju. Pojęcia odwodnienia i przewodnienia, czyli zmniejszenia i zwiększenia objętości wody, są więc ściśle związane $z$ hiperi hiponatremią oraz zmianami osmolalności płynów ustrojowych. Zachowanie się przestrzeni wodnej wewnątrzkomórkowej, zarówno w przypadku odwodnienia, jak i przewodnienia, określają pojęcia „izotoniczne” (PWK nie zmienia się), „hipertoniczne" (PWK zmniejsza się) i „hipotoniczne” (PWK zwiększa się) [3-6].

Podstawą rozpoznania odwodnienia bądź przewodnienia są głównie badania podmiotowe i przedmiotowe. Morfologia krwi obwodowej oraz stężenie białka całkowitego w surowicy korelują ze zmianą objętości osocza i pomagają oszacować stopień wielkości przestrzeni wodnej zewnątrzkomórkowej, a tym samym — stopień odwodnienia lub przewodnienia. Wielkość przestrzeni wodnej wewnątrzkomórkowej można ocenić pośrednio, oznaczając średnią objętość krwinki czerwonej ( $\mathrm{MCV}$, mean corpuscular volume) i średnie stężenie hemoglobiny w erytrocytach (MCHC, mean corpuscular hemoglobin concentration) (tab. 1) [3-7]. Przyczyny i objawy zaburzeń gospodarki wodnej przedstawiono w tabeli $2[3,4,8,9]$.

W przypadku odwodnienia izotonicznego należy uzupełniać płyny (płyny elektrolitowe, roztwory koloidowe, preparaty krwi), tak aby osiągnąć ośrodkowe ciśnienie żylne w zakresie $10-12 \mathrm{~cm}$ $\mathrm{H}_{2} \mathrm{O}$. Płyny podaje się doustnie lub dożylnie zależnie od stopnia odwodnienia i występowania objawów klinicznych. Leczeniem $z$ wyboru jest podawanie 0,9-procentowego roztworu chlorku sodu $(\mathrm{NaCl})$. Niedobór wody można obliczyć według wzoru [3, 4]:

wielkość niedoboru wody $=$ TBW

(całkowita woda w ustroju obliczona jako masa ciała $\mathrm{w} \mathrm{kg} \times 0,6) \times[($ stężenie $\mathrm{Na}$ w surowicy w mol/l/140) - 1] 
Tabela 1. Kliniczny podział zaburzeń gospodarki wodnej — badania laboratoryjne w ocenie stanu nawodnienia pacjenta Table 1. Water balance disturbances - laboratory tests in assessment of hydration status of patient

\begin{tabular}{|c|c|c|c|c|c|c|c|}
\hline Zaburzenie & PWK & PZK & $\mathrm{Na}$ & $\mathrm{Hb}$ & $\mathrm{Ht}$ & Białko & $\mathrm{MCV}$ \\
\hline \multicolumn{8}{|l|}{ Odwodnienie } \\
\hline Izotoniczne & $\mathbf{N}$ & $\downarrow$ & $\mathrm{N}$ & $\uparrow$ & $\uparrow$ & $\uparrow$ & $\mathrm{N}$ \\
\hline Hipertoniczne & $\downarrow$ & $\downarrow \downarrow$ & $\uparrow$ & $\uparrow$ & $\uparrow / N$ & $\uparrow$ & $\downarrow$ \\
\hline Hipotoniczne & $\uparrow$ & $\downarrow$ & $\downarrow$ & $\uparrow$ & $\uparrow \uparrow$ & $\uparrow$ & $\uparrow$ \\
\hline \multicolumn{8}{|l|}{ Przewodnienie } \\
\hline Izotoniczne & $\mathrm{N}$ & $\uparrow$ & $\mathrm{N}$ & $\downarrow$ & $\downarrow$ & $\downarrow$ & $\mathrm{N}$ \\
\hline Hipertoniczne & $\downarrow$ & $\uparrow$ & $\uparrow$ & $\downarrow$ & $\downarrow \downarrow$ & $\downarrow$ & $\downarrow$ \\
\hline Hipotoniczne & $\uparrow$ & $\uparrow$ & $\downarrow$ & $\downarrow$ & $\downarrow / \mathrm{N}$ & $\downarrow$ & $\uparrow$ \\
\hline
\end{tabular}

PWK - płyn wewnątrzkomórkowy; PZK - płyn zewnątrzkomórkowy; $\mathrm{Na}$ - sód; $\mathrm{Hb}$ - hemoglobina; $\mathrm{Ht}$ - hematokryt; $\mathrm{MCV}$ (mean corpuscular volume) — średnia objętość krwinki czerwonej; $\mathrm{N}-$ norma; $\downarrow$ - obniżenie; $\uparrow$ - zwiększenie

Tabela 2. Przyczyny i objawy zaburzeń gospodarki wodnej

Table 2. The causes and symptoms of water disturbances

\begin{tabular}{|c|c|c|}
\hline Zaburzenie & Przyczyny & Objawy \\
\hline Odwodnienie izotoniczne & $\begin{array}{l}\text { Nadmierna utrata płynów izotonicznych } \\
\text { przez przewód pokarmowy i/lub nerki } \\
\text { Utrata krwi } \\
\text { Ucieczka płynów do przestrzeni trzeciej }\end{array}$ & $\begin{array}{l}\downarrow \text { ciśnienia tętniczego, } \downarrow \text { diurezy } \\
\text { Tachykardia } \\
\text { Zmiany czynności OUN (osłabienie, apatia, } \\
\text { zwolnienie reakcji na bodźce zewnętrzne, } \\
\text { śpiączka) } \\
\text { Wzmożone pragnienie }\end{array}$ \\
\hline $\begin{array}{l}\text { Odwodnienie hipertoniczne, } \\
\text { czyli niedobór wolnej wody } \\
\text { (utrata wody przewyższa utratę } \\
\text { sodu) }\end{array}$ & $\begin{array}{l}\text { Niedostateczne przyjmowanie wody } \\
\text { Utrata wody przez skórę, płuca lub utrata } \\
\text { płynów hipotonicznych przez przewód po- } \\
\text { karmowy (wodniste biegunki) i nerki (mo- } \\
\text { czówka prosta, cukrzyca, tubulopatie) }\end{array}$ & $\begin{array}{l}\text { Uczucie silnego pragnienia } \\
\text { Suchość błon śluzowych i skóry } \\
\text { Zaburzenia czynności OUN: omamy, splą- } \\
\text { tanie, niepokój, pobudzenie, drgawki, } \\
\text { śpiączka } \\
\text { Zaburzenia układu sercowo-naczyniowego: } \\
\text { tachykardia, obniżenie ciśnienia tętniczego } \\
\text { i diurezy }\end{array}$ \\
\hline $\begin{array}{l}\text { Odwodnienie hipotoniczne, } \\
\text { czyli niedobór sodu (utrata sodu } \\
\text { przewyższa utratę wody) }\end{array}$ & $\begin{array}{l}\text { Utrata płynów izotonicznych, która jest } \\
\text { wyrównywana podawaniem płynów } \\
\text { bezelektrolitowych } \\
\text { Utrata sodu przez nerki } \\
\text { Zmiany organiczne w OUN } \\
\text { Niewydolność kory nadnerczy }\end{array}$ & $\begin{array}{l}\text { Związane z oligowolemią } \\
\text { Zaburzenia neurologiczne: apatia, bóle } \\
\text { głowy, nudności, zaburzeniami } \\
\text { świadomości, skłonność do drgawek } \\
\text { Chorzy nie skarżą się na pragnienie i często } \\
\text { odczuwają metaliczny smak w ustach }\end{array}$ \\
\hline Przewodnienie izotoniczne & $\begin{array}{l}\text { Niewydolność krążenia } \\
\text { Marskość wątroby } \\
\text { Nadmierna utrata białek przez przewód po- } \\
\text { karmowy lub nerki } \\
\text { Nadmierna podaż izotonicznego roztworu } \\
\mathrm{NaCl}\end{array}$ & Obrzęki \\
\hline Przewodnienie hipertoniczne & $\begin{array}{l}\text { Nadmierna podaż roztworów hiper- } \\
\text { i izotonicznych } \mathrm{NaCl} \text { u osób z ograniczoną } \\
\text { czynnością nerek } \\
\text { Nadmierna podaż hipertonicznych płynów } \\
\text { elektrolitowych } \\
\text { Picie wody morskiej }\end{array}$ & $\begin{array}{l}\text { Obrzęki } \\
\text { Niewydolność lewokomorowa } \\
\text { Zaczerwienienie skóry } \\
\text { Wzmożone pragnienie } \\
\text { Przy znacznym przewodnieniu: zaburzenia } \\
\text { świadomości, śpiączka }\end{array}$ \\
\hline $\begin{array}{l}\text { Przewodnienie hipotoniczne, } \\
\text { czyli zatrucie wodne }\end{array}$ & $\begin{array}{l}\text { Nadmierna podaż płynów bezelektrolito- } \\
\text { wych u chorych ze zmniejszoną czynnością } \\
\text { nerek lub ze zwiększonym wydzielaniem } \\
\text { wazopresyny }\end{array}$ & $\begin{array}{l}\text { Związane z obrzękiem komórek mózgo- } \\
\text { wych: osłabienie, nudności, wymioty, brak } \\
\text { łaknienia, stany splątania, skurcze pojedyn- } \\
\text { czych grup mięśniowych, drgawki, śpiącz- } \\
\text { ka, brak pragnienia }\end{array}$ \\
\hline
\end{tabular}

$\downarrow$ — obniżenie; OUN — ośrodkowy układ nerwowy; $\mathrm{NaCl}$ — chlorek sodu 
W przypadku odwodnienia i przewodnienia hiper- i hipotonicznego postępowanie zależy od stężenia sodu (omówiono je w części dotyczącej leczenia hiper- $\mathrm{i}$ hiponatremii).

\section{Zaburzenia gospodarki sodowej}

\section{Hipernatremia}

Hipernatremia to zwiększenie stężenia sodu w surowicy powyżej $145 \mathrm{mmol} / 1$. Wyróżnia się hipernatremię lagodną ze stężeniem sodu $146-149 \mathrm{mmol} / \mathrm{l}$, umiarkowaną — 150-169 mmol/l i ciężką, w której stężenie wynosi co najmniej $170 \mathrm{mmol} / \mathrm{l}$. Hipernatremii mogą towarzyszyć izowolemia, zmniejszenie ilości wody pozakomórkowej (hipowolemia) lub jej zwiększenie (hiperwolemia) [3, 4].

Przyczyny hipowolemicznej hipernatremii $\mathrm{w}$ onkohematologii to przede wszystkim utrata wody przez przewód pokarmowy i skórę: wymioty, biegunki, nadmierne pocenie, jak również utrata wody przez nerki wywołana stosowaniem diuretyków pętlowych, upośledzoną zdolnością zagęszczania moczu, diurezą osmotyczną (cukrzyca, mannitol) czy fazą wielomoczu w ostrej martwicy cewek. Do przyczyn hipernatremii izowolemicznej należą: zmniejszona podaż wody, zaburzenia odczuwania pragnienia, moczówka prosta. Hipernatremię $z$ hiperwolemią mogą powodować nadmierna podaż sodu (często przy ograniczonym dostępie do wody) lub jatrogenne podawanie hipertonicznych roztworów sodu czy wodorowęglanów, nadmiar glikokortykosteroidów [3-9].

Objawy kliniczne przedstawione $\mathrm{w}$ tabeli 3 pojawiają się przy stężeniu sodu wyższym niż $160 \mathrm{mmol} / \mathrm{l}$ lub gdy hipernatremia rozwija się w sposób nagły (hipernatremia ostra) [3, 4, 10]. Przewlekły wzrost stężenia sodu, trwający dłużej niż 5 dni, często jest dobrze tolerowany. Badania laboratoryjne $z$ oceną stężeń elektrolitów (potasu $\left[\mathrm{K}^{+}\right]$, sodu $\left[\mathrm{Na}^{+}\right]$, wapnia $\left[\mathrm{Ca}^{2+}\right]$ ) w surowicy i w moczu, osmolalności moczu, wskaźników nerkowych i stężenia glukozy pozwalają na różnicowanie rodzaju odwodnienia i przyczyn hipernatremii. Najbardziej wiarygodnym klinicznym parametrem odwodnienia towarzyszącego hipernatremii jest utrata masy ciała [3-9]. Łagodna hipernatremia rzadko wymaga leczenia. W przypadku ciężkiej hipernatremii należy stale monitorować u pacjenta parametry życiowe, bilans płynów, masę ciała oraz stężenia sodu i glukozy. Zbyt gwałtowne zmniejszenie stężenia sodu może powodować obrzęk mózgu, drgawki i trwałe uszkodzenie mózgu. W ostrej hipernatremii trwającej krócej niż 24 h wyrównanie może nastąpić $\mathrm{w}$ ciągu doby, jeśli natomiast hipernatremia jest przewlekła, to okres wyrównywania powinien przekraczać 48 h. W ciężkiej hipernatremii szybkość obniżania stężenia sodu nie powinna być większa niż $12 \mathrm{mmol} / \mathrm{l} /$ dobę. Szybkość nawadniania u pacjenta $z$ hipowolemiczną hipernatremią $\mathrm{w}$ ciągu pierwszych 12-24 h zależy od stężenia sodu; przy stężeniu co najmniej $150 \mathrm{mmol} / \mathrm{l}$ podawanie płynów powinno się odbywać powoli, ze stałą szybkością. Preferuje się podawanie płynów doustnie przez sondę żołądkową $z$ użyciem preparatów o niskiej zawartości sodu (Gastrolit ${ }^{\circledR}$ ). Nawadnianie dożylnie prowadzi się przy użyciu 0,9-procentowego $\mathrm{NaCl}$ i 5-procentowej glukozy, a następnie 0,45-procentowego roztworu $\mathrm{NaCl}$, tak aby korekcja stężenia sodu nie była większa niż $1-2 \mathrm{mmol} / \mathrm{l} / \mathrm{h}$. W ciągu pierwszych 12-24 h należy wyrównać tylko 50\% wielkości niedoboru wody, pozostały deficyt uzupełnia się w ciągu kolejnych 24 h. Stężenia elektrolitów w surowicy i moczu oraz glukozy powinno się kontrolować co 2-4 h, monitorując jednocześnie stan neurologiczny pacjenta i zmniejszając szybkość korekcji stężenia sodu wraz z poprawą kliniczną.

Pacjentom $z$ hipernatremią hiperwolemiczną (ze zwiększoną objętością PZK) należy podawać 5-procentową glukozę i diuretyki pętlowe przez ponad 72-96 h. W przypadku stężenia sodu powyżej $180 \mathrm{mmol} / \mathrm{I}$ należy rozważyć dializoterapię $[3,4,6,8,9]$.

\section{Hiponatremia}

Hiponatremia to zmniejszenie stężenia sodu poniżej $135 \mathrm{mmol} / 1$. Zależnie od efektywnej molalności osocza wyróżnia się hiponatremię izo-, hipo$\mathrm{i}$ hiperwolemiczną. Przyczyny hiponatremii $z$ hipowolemią to utrata sodu i wody przez $[3,4,11,12]$ : - przewód pokarmowy - wymioty, biegunka;

- nerki - tubulopatie, leki moczopędne, diureza osmotyczna (cukrzyca, mannitol);

- skórę - oparzenia;

- utrata wody do trzeciej przestrzeni;

- uzupełnianie strat dzięki podawaniu płynów bezelektrolitowych.

Hiponatremia $z$ izowolemią może wystąpić w przebiegu niedoczynności tarczycy, niedoczynności kory nadnerczy, w tak zwanym zespole utraty soli pochodzenia mózgowego będącego wynikiem nadmiernego wydzielania hormonu antydiuretycznego (ADH, antidiuretic hormone), w polidypsji psychogennej czy w przypadku stosowania leków moczopędnych. Jako rzekomą obserwuje się ją w hiperlipidemii lub paraproteinemii — w szpiczaku plazmocytowym lub makroglobulinemii Waldenströma [3, 4]. Hiponatremia jest obecna u około $10 \%$ pacjentów z ostrymi białaczkami [13]. 
Tabela 3. Objawy zaburzeń elektrolitowych

Table 3. The symptoms of electrolyte disturbances

\begin{tabular}{|c|c|}
\hline Rodzaj dyselektrolitemii & Objawy \\
\hline Hipernatremia & $\begin{array}{l}\text { Objawy neurologiczne: drżenia, wzmożenie odruchów, drgawki, splątanie, ataksja, } \\
\text { zaburzenia świadomości, śpiączka }\end{array}$ \\
\hline Hiponatremia & $\begin{array}{l}\text { Związane z chorobą podstawową } \\
\text { Niespecyficzne, jak ogólne osłabienie, uczucie wyczerpania } \\
\text { Objawy neurologiczne: zaburzenia orientacji, drgawki, śpiączka }\end{array}$ \\
\hline Hiperkaliemia & $\begin{array}{l}\text { Osłabienie mięśni, które może przechodzić w porażenie wiotkie } \\
\text { Kardiotoksyczność przejawiająca się zaburzeniami przewodnictwa } \\
\text { Zmiany w zapisie EKG: skrócenie QT, wysokie spiczaste załamki T, wydłużenie czasu trwania } \\
\text { zespołów QRS } \\
\text { Opóźnienie przewodnictwa przedsionkowo-komorowego, asystolia lub migotanie komór } \\
\text { Upośledzone wydalanie jonów wodorowych z moczem i w konsekwencji kwasica } \\
\text { metaboliczna }\end{array}$ \\
\hline Hipokaliemia & $\begin{array}{l}\text { Osłabienie siły mięśniowej, upośledzenie skurczu mięśni gładkich (zaparcia, niedrożność } \\
\text { porażenna jelit) } \\
\text { Zaburzenia rytmu mięśnia sercowego: dodatkowe pobudzenia komorowe, częstoskurcze, } \\
\text { migotanie przedsionków, zmiany EKG (spłaszczenie załamka T, obniżenie odcinka ST, fala U, } \\
\text { wydłużenie odcinka QT) } \\
\text { Upośledzenie funkcji nerek (defekt zagęszczania moczu) } \\
\text { Upośledzenie funkcji obwodowego i ośrodkowego układu nerwowego (parestezje, } \\
\text { nadpobudliwość nerwowa, apatia, zaburzenia koncentracji, senność, nadmierne pragnienie, } \\
\text { nietolerancja zimna) } \\
\text { Alkaloza nieoddechowa }\end{array}$ \\
\hline Hiperkalcemia & $\begin{array}{l}\text { Osłabienie i uczucie zmęczenia, utrata masy ciała, świąd } \\
\text { Odwodnienie, poliuria z towarzyszącą polidypsją, hiperkalciurią, hiperkaliurią, objawami } \\
\text { niewydolności nerek } \\
\text { Nudności, wymioty, dysfagia, zaparcie, objawy niedrożności przewodu pokarmowego, } \\
\text { choroba wrzodowa żołądka lub dwunastnicy, zapalenie trzustki, kamica żółciowa } \\
\text { Zaburzenia rytmu serca, nadciśnienie tętnicze, nadwrażliwość na glikozydy naparstnicy, } \\
\text { w zapisie EKG wydłużenie odstępu PQ i skrócenie QT, szeroki załamek T } \\
\text { Bóle głowy, zaburzenia orientacji, spowolnienie psychoruchowe, osłabienie odruchów, } \\
\text { senność, śpiączka }\end{array}$ \\
\hline Hipokalcemia & $\begin{array}{l}\text { Jawna i utajona tężyczka: samoistne skurcze mięśni, nadmierna pobudliwość nerwowo- } \\
\text {-mięśniowa } \\
\text { Równoważniki tężyczki: skurcze powiek, krtani, naczyń palców, naczyń wieńcowych, } \\
\text { trzewnych, mózgowych (utrata przytomności, migrena) } \\
\text { Zmiany psychiczne: depresja, psychoza } \\
\text { Zmiany neurologiczne: parkinsonizm, pląsawica } \\
\text { Zmiany troficzne skóry, łamliwość włosów i paznokci, hipoplazja szkliwa } \\
\text { Zespół Raynauda } \\
\text { Zaburzenia żołądkowo-jelitowe (zespół złego wchłaniania) }\end{array}$ \\
\hline
\end{tabular}

EKG - elektrokardiograficzne

Hiponatremia $z$ hiperwolemią występuje w niewydolności krążenia, marskości wątroby, zespole nerczycowym, niewydolności nerek. Objawy kliniczne hiponatremii przedstawiono $\mathrm{w}$ tabeli 3, a algorytm diagnostyczny — na rycinie $1[3,4,10$, $11,14,15]$.

Hiponatremia wymaga powolnej korekty tylko do stężenia $125 \mathrm{mmol} / \mathrm{l}$, powyżej tej wartości stosuje się ograniczenia podaży wody. Zbyt szybkie wyrównywanie lub wysokie stężenie sodu prowadzi do osmotycznego zespołu demielinizacyjnego objawiającego się porażeniem wiotkim, śpiączką i wysoką śmiertelnością.
Restrykcja płynów powinna doprowadzić do ich podawania w ilości około $500 \mathrm{ml}$ mniejszej niż ilość wydalanego w ciągu doby moczu i zwykle musi trwać kilka dni, zanim nastąpi pożądany wzrost stężenia sodu [12, 14].

W hiponatremii ostrej objawowej (rozwijającej się $<24 \mathrm{~h}$ ) należy podać 0,9 -procentowy $\mathrm{NaCl}$ w przypadku hipowolemii i 3-procentowy $\mathrm{NaCl}-$ w izowolemii, w objętości powodującej zwiększenie natremii o $20 \mathrm{mmol} / \mathrm{l} /$ dobę. W przewlekłej hiponatremii ( $>48 \mathrm{~h}$ ) przyrost powinien być wolniejszy i wynosić $10-20 \mathrm{mmol} /$ dobę $\mathrm{z}$ jednoczesnym podawaniem chlorku potasu $[3,4,10,11,14,15]$. 


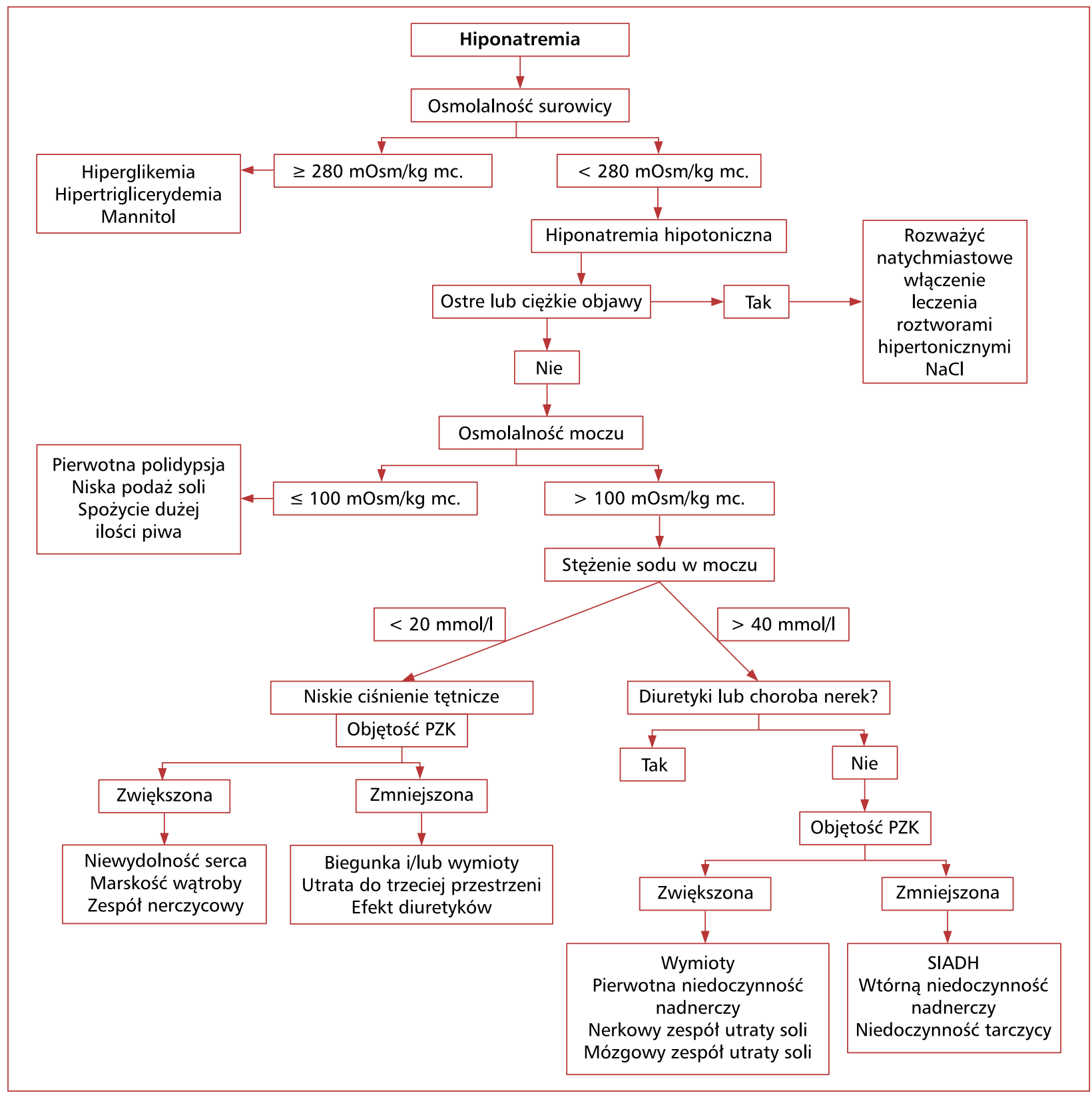

Rycina 1. Algorytm diagnostyczny hiponatremii; $\mathrm{NaCl}$ — chlorek sodu; PZK — objętość przestrzeni pozakomórkowej; SIADH — zespół nieadekwatnego wydzielania hormonu antydiuretycznego

Figure 1. Diagnostic algorithm of hyponatremia; $\mathrm{NaCl}$ - sodium chloride; $\mathrm{PZK}$ - volume of extracellular space; $\mathrm{SIADH}$ - syndrome of inappropriate secretion of anti-diuretic hormone

Ogólny niedobór sodu można obliczyć ze wzoru $[3,4,8]$ :

ogólny niedobór sodu $(\mathrm{mmol})=(140$ - aktualne stężenie $\mathrm{Na}) \times 0,6 \times$ masa ciała $(\mathrm{kg})$

\section{Zespół nieadekwatnego wydzielania hormonu antydiuretycznego}

Najczęstszą przyczyną hiponatremii u pacjentów $z$ chorobami nowotworowymi jest SIADH. 
Jest to paranowotworowy zespół będący wynikiem ektopowego wytwarzania wazopresyny mimo prawidłowej lub zmniejszonej molalności osocza i prawidłowej lub zwiększonej objętości krwi krążącej. Źródłem ADH może być nowotwór lity (najczęściej pluca, głowy i szyi, trzustki) lub nowotwory hematologiczne $[12,14]$.

Zespół SIADH mogą powodować leki stosowane w leczeniu nowotworów [16]. Winkrystyna, a w mniejszym stopniu - winblastyna, poprzez efekt neurotoksyczny na oś podwzgórze-przysadka prowadzi do zaburzenia wydzielania ADH. Cyklofosfamid nie tylko zwiększa sekrecję ADH, ale również wzmacnia jego działanie w nerkach. Pacjenci często przyjmują jednocześnie duże ilości płynów w związku $z$ profilaktyką zapalenia pęcherza moczowego, co może prowadzić do zatrucia wodnego nawet $\mathrm{w}$ przypadku stosowania standardowych dawek cyklofosfamidu. Podawanie cisplatyny może wywołać hiponatremię nie tylko w mechanizmie zespołu SIADH, ale również w wyniku uszkodzenia cewek nerkowych i tak zwanego nerkowego zespołu utraty sodu $[16,17]$. Zwiększone wydzielanie ADH mogą powodować również leki przeciwdepresyjne, opioidowe, przeciwpadaczkowe, przeciwcukrzycowe oraz niesteroidowe leki przeciwzapalne (NLPZ) [14-16].

Kryteria diagnostyczne niezbędne do rozpoznania zespołu SIADH to: zmniejszenie osmolalności osocza poniżej $275 \mathrm{mmol} / \mathrm{kg} \mathrm{mc} . \mathrm{H}_{2} \mathrm{O}$, zwiększenie osmolalności moczu większe niż $100 \mathrm{mmol} / \mathrm{kg} \mathrm{mc} . \mathrm{H}_{2} \mathrm{O}$, brak objawów hipo- lub hiperwolemii, prawidłowa czynność nadnerczy i tarczycy, nieprzyjmowanie leków moczopędnych. Kryteria uzupełniające stanowią: obniżone stężenia kreatyniny, mocznika, kwasu moczowego w surowicy i w moczu, wzrost natremii przy ograniczeniu podaży wody.

Zespól SIADH niekiedy trudno jest różnicować $z$ mózgowym zespołem utraty sodu, który występuje u pacjentów $z$ przerzutami do mózgu, $z$ zajęciem opon mózgowo-rdzeniowych, po urazach głowy czy operacjach neurochirurgicznych. W obu przypadkach podwyższone są osmolalność moczu i stężenie sodu w moczu, ale w zespole SIADH $z$ reguły objętość PZK jest prawidłowa. Różnicowanie jest o tyle istotne, $\dot{z}$ e postępowanie w obu zespołach jest inne, a niewłaściwy wybór leczenia może prowadzić do pogłębienia hiponatremii [18].

Leczenie SIADH polega na ograniczeniu podawania płynów do 500-1000 ml/dobę i ewentualnym wyrównywaniu hiponatremii do wartości $125 \mathrm{mmol} / 1$ [1, 2, 7, 9]. Niekiedy konieczne może być zwiększenie absorpcji sodu w cewkach ner- kowych poprzez zastosowanie fludrokortyzonu $\left(\right.$ Cortineff $\left.{ }^{\circledR}\right)$. Należy jednak pamiętać o monitorowaniu w czasie leczenia stężenia potasu, ciśnienia tętniczego i stanu nawodnienia chorego [10-12,14]. W przypadku nieskuteczności tego postępowania można zastosować leki blokujące receptor wazopresyny (koniwaptan, tolwaptan, mozawaptan) $[11,14,19]$.

\section{Zaburzenia gospodarki potasowej}

\section{Hiperkaliemia}

Hiperkaliemia to zwiększenie stężenia potasu w surowicy powyżej $5,5 \mathrm{mmol} / \mathrm{l}$. W pierwszej kolejności należy wykluczyć hiperkaliemię rzekomą występującą w nadpłytkowości (> $900 \mathrm{G} / \mathrm{l}$ ), hiperleukocytozie ( $>70 \mathrm{G} / \mathrm{l})$ oraz $\mathrm{w}$ hemolizie $[3,4,20]$. Do przyczyn hiperkaliemii należą [3, 4, 21, 22]:

- zmniejszenie wydalania potasu przez nerki (niewydolność nerek, hipoaldosteronizm);

- nadmierne uwalnianie potasu z komórek (zespół rozpadu guza, rabdomioliza, sepsa);

- zwiększenie podaży potasu (doustne preparaty potasu);

- stosowanie przetoczeń krwi oraz leków (moczopędnych oszczędzających potas, NLPZ, inhibitorów konwertazy angiotensyny, leków beta-adrenolitycznych, heparyny i trimetoprimu) [23].

Objawy hiperkaliemii przedstawiono w tabeli 3 [3, 4, 20-22]. Leczenie jest uwarunkowanie nasileniem tego zaburzenia. Przy stężeniu $\mathrm{K}^{+}$powyżej $6 \mathrm{mmol} / \mathrm{l}$ lub bez względu na stężenie potasu, jeśli wystąpią zmiany w zapisie elektrokardiograficznym (EKG), osłabienie siły mięśniowej, niedowład wiotki, parestezje, zwłaszcza w warunkach hipoksji, to należy podać:

- $\quad 10-20 \mathrm{ml} 10$-procentowego glukonianu wapnia dożylnie $\mathrm{w}$ bolusie (nie obniża stężenia potasu, ale zmiany w zapisie EKG mogą się znormalizować nawet w ciagu 1-3 min, efekt ten przemija po ok. $30 \mathrm{~min}$ ), u pacjentów przyjmujących digoksynę glukonian wapnia należy podawać w 20 -minutowym wlewie w $100 \mathrm{ml}$ 5 -procentowej glukozy;

- 6-10 j. insuliny krystalicznej w bolusie, a następnie glukozę (ok. 3 g glukozy/j. insuliny) w celu przesunięcia jonów potasowych do wnętrza komórek;

- leki beta-mimetyczne wziewnie lub dożylnie (np. salbutamol 2,5 $\mathrm{mg}$ co $15 \mathrm{~min}$ do dawki 10-20 mg wziewnie lub 0,5 mg dożylnie).

Jednocześnie należy ograniczyć podaż potasu, odstawić leki podwyższające jego stężenie, ewen- 
tualnie podać diuretyki pętlowe. Nadmiar potasu można usunąć, stosując żywicę jonowymienną (Resonium $\mathrm{A}^{\circledR}$ ) oraz leki przeczyszczające. Przy znacznej hiperkaliemii, szczególnie w przypadku wspólistniejącej niewydolności nerek, należy zastosować dializoterapię. W szczególnych przypadkach $\mathrm{u}$ chorych na cukrzycę $z$ hipoaldosteronizmem należy podać fluorokortyzon w dawce $0,5 \mathrm{mg} /$ dobę, a w razie podejrzenia niedoczynności nadnerczy glikokortykosteroidy [3, 4, 21, 24, 25].

\section{Hipokaliemia}

Hipokaliemia to zmniejszenie stężenia potasu w surowicy poniżej $3,5 \mathrm{mmol} / \mathrm{l}$. W pierwszej kolejności należy wykluczyć hipokaliemię rzekomą (krew pobrana 20-30 min po podaniu insuliny) oraz hipokaliemię uwarunkowaną transmineralizacją, czyli przemieszczeniem potasu pozakomórkowego do komórek po podaniu leków beta-adrenergicznych, bronchodylatatorów, teofiliny, kofeiny, w trakcie intensywnej insulinoterapii, $\mathrm{w}$ hiperaldosteronizmie, w przypadku intensywnego odżywiania osób uprzednio głodzonych lub niedożywionych, przedawkowaniu werapamilu, chlorochiny, w przypadku gwałtownej proliferacji komórek nowotworowych (ostre białaczki, niedokrwistość złośliwa leczona witaminą $\mathrm{B}_{12}$ ) [3, 4, 26, 27]. Hipokaliemia może być spowodowana [3, 4, 20, 21, 26, 27]:

- niedostateczną podażą potasu;

- nadmierną utratą potasu przez przewód pokarmowy i skórę: wymioty, biegunki, nadmierne poty i oparzenia;

- nadmierną utratą potasu przez nerki: nefropatia $z$ utratą soli, diureza osmotyczna w cukrzycy, hiperaldosteronizm pierwotny lub wtórny (w przebiegu przewlekłej niewydolności krążenia, w marskości wątroby, w nadciśnieniu tętniczym naczyniowo-nerkowym, w chorobie/zespole Cushinga), w przypadku stosowania leków (diuretyków pętlowych, tiazydowych, kortykosteroidów, amfoterycyny B, cisplatyny, aminoglikozydów, sirolimusu, leków przeczyszczających czy żywic wiążących potas) oraz w stanach nadmiernej diurezy.

Lekiem cytostatycznym szczególnie związanym $z$ występowaniem hipokaliemii jest ifosfamid, który powoduje utratę potasu poprzez uszkodzenie lub martwicę cewek proksymalnych w nerkach (zespół Fanconiego). Niestety, zmiany te mogą się utrzymywać miesiące, a nawet wiele lat po zakończeniu leczenia [28]. U pacjentów $z$ nowotworami hematologicznymi hipokaliemia występuje szczególnie często (43-64\%) w ostrych białaczkach szpikowych M4 i M5. Jest najprawdopodobniej spowodowana przez zwiększone wydzielanie lizozymu i lizozynurię, która prowadzi do uszkodzenia cewek nerkowych. Innym mechanizmem może być zwiększona aktywacja reniny przez komórki bialaczkowe i w konsekwencji zwiększona produkcja mineralokortykoidów [13, 29, 30].

Ciężkość objawów przedstawionych w tabeli 3 zależy od stopnia nasilenia i szybkości narastania hipokaliemii [3, 4, 20, 21, 26, 27]. U chorego bez objawów klinicznych najlepiej uzupełniać potas doustnie. Szacowany niedobór potasu przy zmniejszeniu kaliemii o $1 \mathrm{mmol} / 1$ to $150 \mathrm{mmol}$. Można zastosować leki moczopędne oszczędzające potas. W przypadku wystąpienia zaburzeń rytmu serca konieczne jest pozajelitowe podawanie 15-procentowego roztworu $\mathrm{KCl} \mathrm{w} \mathrm{5-procentowej} \mathrm{glukozie;} \mathrm{szybkość} \mathrm{wlewu}$ nie powinna przekraczać $20 \mathrm{mmol} / \mathrm{h}$. Można też, szczególnie u chorych na cukrzycę, dodać na każde 3 g podawanej glukozy $1 \mathrm{j}$. insuliny krystalicznej. Konieczność szybkiego wyrównania (chorzy ze współistniejącą zasadowicą) lub podawania roztworów o wysokim stężeniu wymaga dostępu do dużego naczynia żylnego. Podawanie $\mathrm{KCl}$ do żył obwodowych jest bolesne i może powodować obturację naczynia. Należy oznaczyć stężenie magnezu, ponieważ hipomagnezemia utrudnia wyrównanie hipokaliemii [3, 4, 21, 22, 26, 27].

\section{Zaburzenia gospodarki wapniowej}

\section{Hiperkalcemia}

Hiperkalcemia to podwyższenie stężenia wapnia całkowitego w surowicy powyżej 2,6 mmol/l (10,5 mg/ /dl) lub stężenia wapnia zjonizowanego powyżej $1,25 \mathrm{mmol} / \mathrm{l}(5,0 \mathrm{mg} / \mathrm{dl})$. W praktyce klinicznej oznacza się stężenie wapnia całkowitego, które słabo koreluje ze stężeniem wapnia zjonizowanego i zależy od objętości osocza i stężenia albumin [3, 4, 31]. W przypadku wspólistnienia zaburzeń w stężeniach białek surowicy należy obliczyć tak zwane skorygowane stężenie wapnia według wzoru [3,4,31, 32]:

$$
\begin{gathered}
\text { skorygowane stężenie wapnia }(\mathrm{mg} / \mathrm{dl}) \\
=[\text { zmierzone stężenie wapnia }(\mathrm{mg} / \mathrm{dl}) \\
- \text { stężenie albumin }(\mathrm{g} / \mathrm{dl})]+4
\end{gathered}
$$

Najczęstsze przyczyny hiperkalcemii to pierwotna nadczynność przytarczyc i nowotwory, ale może też być spowodowana zaburzeniami metabolizmu lub przedawkowaniem witaminy $\mathrm{D}_{3}$, długotrwałym unieruchomieniem, leczeniem diuretykami tiazydowymi, litem oraz lekami alkalizującymi sok żołądkowy [3, 4, 33]. W hiperproteinemii 


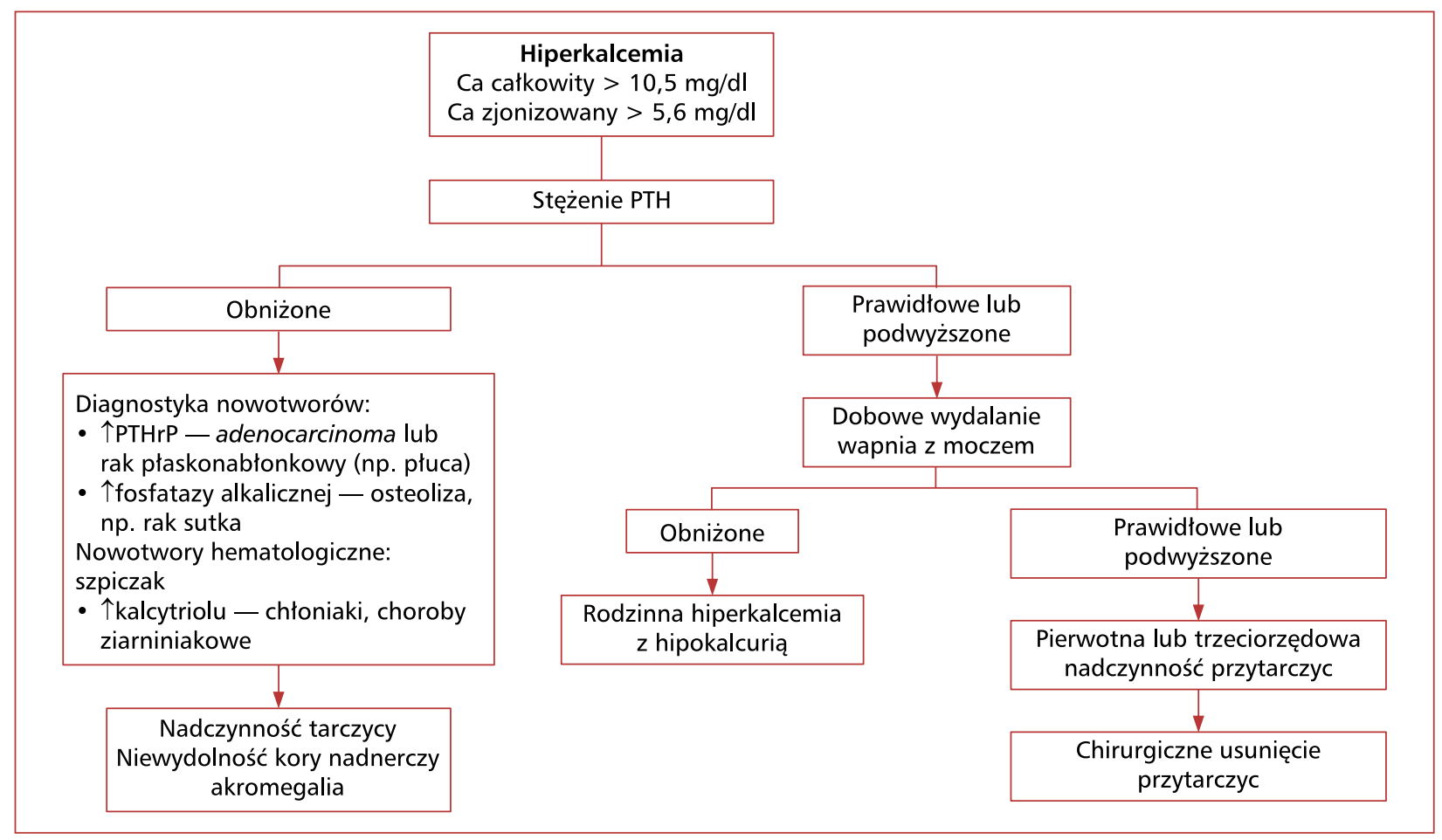

Rycina 2. Algorytm diagnostyczny hiperkalcemii; Ca - wapń; PTH - parathormon; PTHrP — białko związane z parathormonem

Figure 2. Diagnostic algorithm of hypercalcemia; Ca - calcium, PTH - parathyroid hormone; PTHrP - parathormone-related peptide

może wystąpić hiperkalcemia rzekoma [31, 34]. $\mathrm{W}$ rozrostach hematologicznych, hiperkalcemia najczęściej występuje w szpiczaku plazmocytowym [35], białaczce/chłoniaku T-komórkowym dorosłych [36], chłoniakach B-komórkowych i przewlekłej białaczce limfocytowej [37, 38]. Jest stosunkowo rzadkim powikłaniem ostrej i przewlekłej białaczki szpikowej [39, 40] czy ostrej białaczki limfoblastycznej [41]. Do hiperkalcemii dochodzi za pośrednictwem uwalnianych cytokin (czynnika martwicy nowotworów [TNF, tumor necrosis factor], interleukiny 1 [IL-1], IL-6, receptora aktywatora czynnika jądrowego $\kappa \mathrm{B}$ [RANK, receptor activator for nuclear factor $\kappa B]$ /ligandu receptora aktywatora czynnika jądrowego $\kappa \mathrm{B}$ [RANKL, receptor activator for nuclear factor $\kappa B$ ligand]/osteoprotegeryny [OPG, osteoprotegerin]), białka związanego $\mathrm{Z}$ parathormonem (PTHrP, parathormone-related peptide), prostaglandyn klasy $\mathrm{PGE}_{2}$, czynnika aktywującego osteoklasty (OAF, osteoclast activating factor) [31, 32, 42]. Schemat diagnostyczny hiperkalcemii przedstawiono na rycinie 2 .

Objawy hiperkalcemii przedstawiono w tabeli 3 [3, 4, 31, 32, 42, 43]. W umiarkowanej i ciężkiej lub szybko narastającej hiperkalcemii może wy- stąpić przełom hiperkalcemiczny $z$ dominującymi objawami neurologicznymi, wymiotami, bólami brzucha, zaburzeniami rytmu serca oraz znacznym odwodnieniem. Terapia obejmuje leczenie przyczyn prowadzących do hiperkalcemii oraz leczenie objawowe, do którego należą [3, 4, 31-33]:

- nawodnienie: w przewlekłej hiperkalcemii stosuje się doustnie płyny w ilości 3-4 1/dobę; w objawowej hiperkalcemii podaje się 0,9 -procentowy $\mathrm{NaCl}$ dożylnie w ilości $3 \mathrm{l} / \mathrm{m}^{2} /$ dobę;

- wymuszona diureza za pomocą furosemidu wynosząca $150-200 \mathrm{ml} / \mathrm{h}$;

- wyrównanie wspólistniejących zaburzeń gospodarki wodno-elektrolitowej i kwasowo-zasadowej;

- bifosfoniany stosuje się dożylnie, jeśli przesączanie kłębuszkowe (GFR, glomerular filtration rate) wynosi powyżej $30 \mathrm{ml} / \mathrm{min}$; w hiperkalcemii przewlekłej do rozważenia pozostaje podanie klodronianu doustnie. Jeśli istnieją istotne przeciwwskazania do zastosowania bifosfonianów (ciężka niewydolność nerek), to można podać kalcytoninę w dawce $1 \mathrm{jm} . / \mathrm{kg} \mathrm{mc} . / \mathrm{h}$ dożylnie albo podskórnie lub domięśniowo w dawce 100 jm. 2-4 razy w ciągu doby; 
- glikokortykosteroidy (hydrokortyzon w dawce $250-500 \mathrm{mg}$ dożylnie co $8 \mathrm{~h}$; prednizon w dawce $10-100 \mathrm{mg} / \mathrm{d}$.);

- $\quad$ w przypadkach opornej na leczenie hiperkalcemii można zastosować mitramycynę, azotan galu lub skierować chorego na dializoterapię.

\section{Hipokalcemia}

Hipokalcemia to obniżenie stężenia wapnia całkowitego w surowicy poniżej $2,2 \mathrm{mmol} / 1(8,8 \mathrm{mg} /$ /dl) u chorych $z$ prawidłowym stężeniem białka w surowicy. Do przyczyn hipokalcemii należą: pierwotna i wtórna niedoczynność przytarczyc, zaburzenia gospodarki witaminą $\mathrm{D}$, zaburzone wchłanianie wapnia $z$ przewodu pokarmowego, nadmierne odkładanie soli wapnia (ostre zapalenie trzustki), nadmierna utrata wapnia $z$ moczem (kwasica metaboliczna, stosowanie furosemidu), hiperfosfatemia, hipoproteinemia, polekowa hipokalcemia (stosowanie mitramycyny, cytrynianu, wersenianu sodu, kolchicyny, kalcytoniny, bifosfonianów) [3, 4, 31, 43]. Objawy hipokalcemii przedstawiono w tabeli 3 [3, 4, 31, 43].

Leczenie w przypadkach wystąpienia objawów tężyczki, drgawek czy zaburzeń rytmu serca polega na podaniu $10 \mathrm{ml} 10$-procentowego $\mathrm{NaCl} \mathrm{w}$ bolusie, a następnie 1 litra 5-procentowej glukozy $\mathrm{z} \mathrm{NaCl}$ w ciągu $12-24$ h. Należy pamiętać, że podanie stężonego roztworu $\mathrm{NaCl}$ poza żyłę może spowodować martwicę tkanek, dlatego można zastosować glukonian wapnia $[4,31,43]$. W przewlekłej hipokalcemii stosuje się doustne preparaty wapnia i witaminy D. Konieczne jest wyrównanie współistniejącej hipomagnezemii [3, 4, 31, 43].

\section{Zaburzenia równowagi kwasowo-zasadowej}

Podstawę rozpoznania zaburzeń równowagi kwasowo-zasadowej (ABB, acid-base balance) stanowi badanie gazometryczne krwi tętniczej lub arterializowanej krwi włośniczkowej. Zasady oceny stanu ABB muszą uwzględniać wpływ zmian wartości wykładnika oddechowego $\left(\mathrm{pCO}_{2}\right)$ i metabolicznego $\left(\mathrm{HCO}_{3}{ }^{-}\right.$). Zaburzenia ABB mogą być pierwotne spowodowane nieprawidłowym funkcjonowaniem układów regulacyjnych płuc lub nerek oraz wtórne - spowodowane nieprawidłowym metabolizmem lub niekontrolowaną utratą/podażą kwasów lub zasad. W prawidłowych warunkach dochodzi do wyrównania zaburzeń RKZ poprzez zmianę tych parametrów równowagi, które nie były przyczyną zaburzenia.

Zależnie od wartości pH rozróżnia się zaburzenia $\mathrm{ABB}$ całkowicie lub częściowo wyrównane oraz niewyrównane $[44,45]$. Przyczyny i objawy tych zaburzeń wymieniono w tabeli 4 [44-47]. Najistotniejszym elementem diagnostyki jest prawidlowa interpretacja badania gazometrycznego krwi, która powinna obejmować: ocenę $\mathrm{pH}$ (kwasica/ /zasadowica), określenia pierwotnego charakteru zaburzeń (oddechowy/metaboliczny), obliczenie luki anionowej (różnica stężeń sodu i sumy stężeń jonów $\mathrm{Cl}^{-} \mathrm{i}_{\mathrm{HCO}_{3}}^{-}$) i stopnia wyrównania zaburzeń.

U pacjentów $z$ nowotworowymi chorobami hematologicznymi, przede wszystkim chłoniakami nieziarniczymi (NHL, non-Hodgkin lymphoma) i ostrą białaczką limfoblastyczną, najczęściej występuje kwasica metaboliczna mleczanowa [2]. W patomechanizmie jej powstawania biorą udział: insulinopodobny czynnik wzrostu wydzielany przez komórki nowotworowe nasilający glikolizę, co prowadzi do nadprodukcji mleczanów, niedobór tiaminy (witamina $\mathrm{B}_{1}$ ), zmniejszony klirens wątrobowy mleczanów spowodowany obecnością nacieków nowotworowych [2, 48]. Kwasica metaboliczna u pacjentów ze schorzeniami onkohematologicznymi jest stanem zagrożenia życia i wymaga natychmiastowego leczenia, przede wszystkim włączenia chemioterapii ratunkowej. W leczeniu wspomagającym stosuje się dializoterapię, suplemantację tiaminy. W kwasicach $\mathrm{z}$ prawidłową luką anionową 8-14 mEq/1 (różnica stężeń sodu i sumy stężeń jonów $\mathrm{Cl}^{-} \mathrm{i} \mathrm{HCO}_{3}^{-}$) podaje się wodorowęglany. Liczbę wodorowęglanów można obliczyć ze wzoru [44, 45]:

$$
\begin{gathered}
\text { liczba } \mathrm{NaHCO}_{3}=\left(\text { stężenie docelowe } \mathrm{HCO}_{3}^{-}\right. \\
\left.- \text {stężenie aktualne } \mathrm{HCO}_{3}^{-}\right) \\
\times \text {masa ciała } \times 0,4
\end{gathered}
$$

W zależności od stanu wolemii $\mathrm{NaHCO}_{3}$ podaje się w 5 -procentowej glukozie lub 0,45-procentowym $\mathrm{NaCl}$. Docelowo stężenie $\mathrm{HCO}_{3}{ }^{-}$powinno wynosić $15-18 \mathrm{mmol} / \mathrm{l}$. Szybkość podawania zależy od nasilenia kwasicy oraz szybkości narastania i wydolności układu sercowo-naczyniowego. W kwasicach ze zwiększoną luką anionową stosowanie $\mathrm{NaHCO}_{3}$ pozostaje dyskusyjne $[2,48]$.

Łagodna zasadowica metaboliczna nie wymaga leczenia; należy dążyć do usunięcia przyczyny upośledzenia wydalania $\mathrm{HCO}_{3}{ }^{-}$przez nerki i wyrównać niedobory płynów, podając roztwór $\mathrm{NaCl}$, a w przypadkach opornych na takie leczenie - dołączyć suplementację potasem. W zasadowicy oddechowej należy leczyć chorobę podstawową, podawać leki uspokajające lub działające depresyjnie na ośrodek oddechowy oraz stosować metodę oddychania do plastikowego worka. W kwasicy oddechowej 
Tabela 4. Przyczyny i objawy pierwotnych zaburzeń równowagi kwasowo-zasadowej

Table 4. The causes and symptoms of acid-base balance disorders

\begin{tabular}{|c|c|c|}
\hline Zaburzenie & Przyczyny & Objawy \\
\hline $\begin{array}{l}\text { Kwasica metaboliczna } \\
\downarrow \mathrm{pH} \\
\mathrm{N} / \downarrow \mathrm{pCO}_{2} \\
\downarrow \downarrow \mathrm{HCO}_{3} \\
\mathrm{~N} / \uparrow \downarrow \mathrm{K}^{+}\end{array}$ & $\begin{array}{l}\text { Biegunki, obecność przetok } \\
\text { Kwasice cewkowe } \\
\text { Cukrzyca (kwasice ketonowe lub mleczanowe) } \\
\text { Przewlekły alkoholizm } \\
\text { Nadczynność przytarczyc } \\
\text { Hipoaldosteronizm pierwotny } \\
\text { Kwasice polekowe } \\
\text { Zatrucia (metanol, glikol, salicylany) }\end{array}$ & $\begin{array}{l}\text { Objawy choroby podstawowej } \\
\text { Nudności, wymioty } \\
\text { Zwiększona wentylacja w nasilonej kwasicy } \\
\text { (oddech Kussmaula) } \\
\text { Objawy odwodnienia, zwłaszcza u pacjentów } \\
\text { z kwasicą ketonową lub z towarzyszącą } \\
\text { utratą płynów z przewodu pokarmowego }\end{array}$ \\
\hline $\begin{array}{l}\text { Zasadowica metaboliczna } \\
\uparrow p \mathrm{H} \\
\mathrm{N} / \uparrow \mathrm{pCO}_{2} \\
\uparrow \uparrow \mathrm{HCO}_{3} \\
\mathrm{~N} / \downarrow \mathrm{K}^{+}\end{array}$ & $\begin{array}{l}\text { Utrata jonów } \mathrm{H}^{+} \text {: przedłużające się wymioty, } \\
\text { odsysanie treści żołądkowej, nadmierna } \\
\text { utrata chlorków przez przewód pokarmowy } \\
\text { lub z moczem } \\
\text { Nadmierna podaż substancji alkalizujących } \\
\text { - tzw. milk-alkali syndrome }\left(\mathrm{CaCO}_{3}\right) \\
\text { Przesunięcie jonów } \mathrm{H}^{+} \text {do wnętrza komórek: } \\
\text { hipokaliemia, hipowolemia, hipomagnezemia }\end{array}$ & $\begin{array}{l}\text { Brak specyficznych objawów } \\
\text { W ciężkich zaburzeniach: apatia, stany } \\
\text { splątania, stupor } \\
\text { W przypadku jednoczesnego granicznego stę- } \\
\text { żenia wapnia może wystąpić tężyczka }\end{array}$ \\
\hline $\begin{array}{l}\text { Kwasica oddechowa } \\
\downarrow \mathrm{pH} \\
\uparrow \uparrow \mathrm{pCO}_{2} \\
\mathrm{~N} / \uparrow \mathrm{HCO}_{3} \\
\mathrm{~N} / \uparrow \mathrm{K}^{+}\end{array}$ & $\begin{array}{l}\text { Uszkodzenie nerwowej regulacji oddychania } \\
\text { (w OUN) } \\
\text { Ograniczenie ruchomości klatki piersiowej } \\
\text { (np. tężec) } \\
\text { Porażenie neuronów ruchowych (polio, } \\
\text { miastenia, zespół Guillain-Barré, zatrucie } \\
\text { kurrarą) } \\
\text { Choroby płuc i opłucnej (płyn w jamie } \\
\text { opłucnej, odma opłucnowa) } \\
\text { Choroby serca (niewydolność serca) } \\
\text { Zaburzenia sztucznego oddechu } \\
\text { kontrolowanego }\end{array}$ & $\begin{array}{l}\text { Dominują objawy choroby podstawowej } \\
\text { Encefalopatia: bóle głowy, senność, stan } \\
\text { stuporu, śpiączka } \\
\text { Drżenia grubofaliste i drgawki wieloogniskowe } \\
\text { Obrzęki obwodowe } \\
\text { Zaburzenia rytmu serca }\end{array}$ \\
\hline $\begin{array}{l}\text { Zasadowica oddechowa } \\
\uparrow \mathrm{pH} \\
\downarrow \downarrow \mathrm{pCO}_{2} \\
\mathrm{~N} / \downarrow \mathrm{HCO}_{3} \\
\mathrm{~N} / \downarrow \mathrm{K}^{+}\end{array}$ & $\begin{array}{l}\text { Hiperwentylacja - sytuacje stresowe (ból, lęk) } \\
\text { Czynniki drażniące ośrodek oddechowy } \\
\text { (gorączka, toksyny, leki salicylany) } \\
\text { Choroby serca i płuc } \\
\text { Marskość wątroby } \\
\text { Zmiany zwyrodnieniowe w OUN (stymulacja } \\
\text { ośrodka oddechowego) } \\
\text { Posocznica Gram-ujemna }\end{array}$ & $\begin{array}{l}\text { Objawy choroby podstawowej } \\
\text { Skurcz naczyń krążenia mózgowego wywołuje } \\
\text { objawy niedotlenienia OUN: tężyczka, } \\
\text { parestezje, zawroty głowy, uczucie } \\
\text { omdlewania, utrata przytomności }\end{array}$ \\
\hline
\end{tabular}

$\downarrow$ — obniżenie; $\uparrow$ — zwiększenie; N — norma; OUN — ośrodkowy układ nerwowy

powinno się dążyć do poprawy wentylacji i/lub perfuzji płuc $z$ zastosowaniem mechanicznego wspomagania oddechu włącznie [44-47].

\section{Zespół rozpadu guza}

Zespól rozpadu guza jest stanem zagrożenia życia występującym u pacjentów $\mathrm{z}$ nowotworami, u których w wyniku rozpadu komórek nowotworowych i uwolnienia ich zawartości dochodzi do wystąpienia zaburzeń metabolicznych i ich następstw klinicznych mogących prowadzić do zgonu. Najczęściej TLS występuje w nowotworach hematologicznych szybko proliferujących, takich jak ostre białaczki i chłoniaki o wysokim stopniu złośliwości - często już w chwili rozpoznania, co jest spowodowane nasilonym katabolizmem i obrotem komórek białaczkowych. Jednak znacznie częściej TLS jest indukowany przez wdrożenie intensywnej chemioterapii [49-51].

Obraz kliniczny TLS wiąże się $z$ obecnością i stopniem nasilenia zaburzeń elektrolitowych i metabolicznych. Do najgroźniejszych należą zaburzenia rytmu serca, ostra niewydolność nerek, niewydolność krążenia oraz drgawki. W diagnostyce różnicowej należy uwzględnić inne przyczyny uszkodzenia nerek, takie jak posocznica, pozanerkowa niewydolność nerek, toksyczne uszkodzenie polekowe, użycie kontrastu do badań obrazowych, rabdomioliza czy pierwotne glomerulopatie [19, 49-52].

Kryteria laboratoryjne TLS są następujące [40]:

1) stężenie kwasu moczowego co najmniej $8 \mathrm{mg} /$ /dl (lub wzrost o 25\%);

2) stężenie fosforanów nie mniejsze niż $4,5 \mathrm{mg} /$ /dl (lub wzrost o 25\%); 
3) stężenie potasu co najmniej $6,0 \mathrm{mmol} / \mathrm{l}$ (lub wzrost o 25\%);

4) stężenie wapnia nie większe niż $7 \mathrm{mg} / \mathrm{dl}$ (lub spadek o $5 \%$ ).

Do kryteriów klinicznych TLS należą [40]:

1) zaburzenia rytmu serca lub nagły zgon sercowy;

2) drgawki lub cechy nadpobudliwości nerwowo-mięśniowej;

3) hipotensja, niewydolność serca;

4) ostre uszkodzenie nerek: stężenie kreatyniny — wzrost o $0,3 \mathrm{mg} / \mathrm{dl}$ lub 1,5-krotnie powyżej normy albo oliguria co najmniej $6 \mathrm{~h}(<0,5 \mathrm{ml} /$ $/ \mathrm{kg} \mathrm{mc} . / \mathrm{h}$ ).

Do rozpoznania utajonego (laboratoryjnego) TLS konieczne jest spełnienie przynajmniej 2 z 4 laboratoryjnych kryteriów w ciągu 3 dni przed rozpoczęciem do 7 dni po rozpoczęciu chemioterapii. Klinicznie jawny TLS rozpoznaje się natomiast wtedy, gdy laboratoryjnemu TLS towarzyszy jedno z 4 kryteriów klinicznych [49].

Zespół rozpadu guza może się rozwijać bardzo szybko, dlatego ważne jest określenie czynników ryzyka jego rozwoju i włączenie leczenia profilaktycznego. Czynniki ryzyka rozwoju tego zespołu zależne od nowotworu to: szybka proliferacja komórek, duża masa guza (rozmiary, 2-krotny wzrost aktywności dehydrogenazy mleczanowej [LDH, lactate dehydrogenase], liczba krwinek białych $>25 \mathrm{G} / \mathrm{l}$ ), rozległe zajęcie szpiku kostnego lub układu limfatycznego, wrażliwość na chemioterapię. Czynniki zależne od chorego mogą być następujące: podwyższone wyjściowo stężenie kwasu moczowego/fosforanów w surowicy, odwodnienie, niskie $\mathrm{pH}$ moczu, skąpomocz, istniejąca nefropatia, zaawansowany wiek. Wśród czynników zależnych od leczenia należy wymienić: intensywną terapię wielolekową, wspomagającą radioterapię $[49,50$, 52 , 53]. Podstawą zarówno profilaktyki, jak i leczenia TLS są odpowiednie nawadnianie chorego i monitorowanie parametrów biochemicznych. Postępowanie profilaktyczne w TLS, w zależności od typu choroby i stopnia ryzyka rozwoju, przedstawiono w tabeli 5 [49-53].

Zapobieganie i leczenie hiperfosfatemii polega na podawaniu leków wiążących fosfor w przewodzie pokarmowym (chlorowodorek sewelameru, wodorotlenek glinu, węglan lantanu) [53, 54]. Leczenie hiperkaliemii i hipokalcemii opisano w częściach artykułu poświęconych tym zaburzeniom elektrolitowym. Leczenie chorych na TLS może wymagać stosowania dializoterapii. Wskazaniami do leczenia nerkozastępczego tego zespołu są: przedłużający się bezmocz/skąpomocz (> $12 \mathrm{~h}$ ), hiperkaliemia
$>6,5 \mathrm{mmol} / \mathrm{l}$ lub szybki wzrost stężenia potasu, hiperfosfatemia $z$ objawową hipokalcemią, zagrażający obrzęk płuc, przełom nadciśnieniowy oporny na farmakoterapię lub obrzęk mózgu, ciężka kwasica $\left(\mathrm{HCO}_{3}{ }^{-}<13 \mathrm{mmol} / \mathrm{l}\right)$ i objawowa mocznica $[49,50,52,53]$.

\section{Hipoglikemia i hiperglikemia}

Hipoglikemia jest najważniejszym objawem wyspiaka trzustki, ale może również występować w przebiegu innych chorób nowotworowych, w tym NHL, chłoniaka Hodgkina i szpiczaka plazmocytowego. Określa się ją wówczas mianem hipoglikemii nowotworowej niezwiązanej $z$ wyspiakiem (NICTH, non-islet-cell tumor hypoglycemia) [2]. Głównym czynnikiem odpowiedzialnym za zmniejszenie stężenia glukozy w surowicy jest insulinopodobny czynnik wzrostu 2 (IGF-2, insulin-like growth factor-2) i jego prekursor o zwiększonej masie molekularnej (big IGF-2) produkowany przez komórki nowotworowe [55]. Hipoglikemię NICTH może powodować także obecność przeciwciał przeciwko insulinie i receptorowi insulinowemu, ektopowe wydzielanie insuliny lub insulinopodobnego czynnika wzrostu 1 (IGF-1, insulin-like growth factor-1), zaburzenia czynności wątroby lub nadnerczy w następstwie nacieków nowotworowych, wytwarzanie cytokin wykazujących działanie hipoglikemiczne oraz zwiększony wychwyt i metabolizm glukozy przez komórki nowotworowe [56-58].

Obserwowano również jatrogenną hipoglikemię $\mathrm{w}$ przebiegu leczenia rytuksymabem [59], inhibitorami kinaz tyrozynowych [60], analogami puryn [61], a także w trakcie leczenia antybiotykami, trimetopri$\mathrm{mem} / \mathrm{sulfametoksazolem} \mathrm{i} \mathrm{lewofloksacyną} \mathrm{[62,} \mathrm{63].}$ Hipoglikemia nowotworowa niezwiązana $z$ wyspiakiem występuje najczęściej u starszych pacjentów $\mathrm{z}$ chorobami nowotworowymi w zaawansowanym stadium, ale czasami może być wczesną manifestacją choroby nowotworowej [2, 55, 64].

Hipoglikemia w NITCH ma najczęściej charakter trwały, niekiedy stężenie glukozy zmniejsza się do wartości powodujących wystąpienie objawów neurologicznych, do śpiączki włącznie [55, 64]. Rozpoznanie NICTH potwierdzają niskie stężenie insuliny $(1,4-3,6 \mathrm{mjm} . / \mathrm{l})$, obniżone stężenia peptydu C ( $<0,3 \mathrm{ng} / \mathrm{ml})$, kwasu $\beta$-hydroksymasłowego i wolnych kwasów tłuszczowych oraz nieprawidłowy stosunek IGF-2 do IGF-1 [58, 64].

Podstawowym leczeniem hipoglikemii NICTH jest terapia przeciwnowotworowa. W postępowaniu $\mathrm{u}$ pacjenta $\mathrm{z}$ hipoglikemią NICTH należy przede wszystkim zalecić częste spożywanie posiłków, 
Tabela 5. Profilaktyka zespołu lizy guza w zależności od stopnia ryzyka jego rozwoju

Table 5. Prophylaxis of the tumor lysis syndrome according to the risk of its development

\begin{tabular}{|c|c|c|}
\hline Ryzyko & Typ choroby & Postępowanie \\
\hline Wysokie & $\begin{array}{l}\text { Chłoniak Burkitta z LDH }>2 \times \text { ULN } \\
\text { ALL z WBC }>100 \mathrm{G} / \mathrm{l} \\
\text { AML z WBC }>50 \mathrm{G} / \mathrm{l} \\
\text { Chłoniaki o wysokim stopniu złośliwości bulky } \\
\text { z LDH }>2 \times \text { ULN }\end{array}$ & $\begin{array}{l}\text { Płyny infuzyjne } 3 \mathrm{l} / \mathrm{m}^{2} / 24 \mathrm{~h} \text { (diureza godzinowa } \\
>80-100 \mathrm{ml} / \mathrm{m}^{2} \text { ); w przypadku niedostatecznej } \\
\text { diurezy diuretyk pętlowy } \\
\text { Monitorowanie: bilans wodny, wskaźniki nerkowe, } \\
\text { stężenie w surowicy potasu, wapnia, fosforanów, } \\
\text { kwasu moczowego, aktywność LDH co } 4-6 \mathrm{~h} \\
\text { po podaniu chemioterapii przez } \geq 1 \mathrm{dzień} \\
\text { Rasburykaza } 0,2 \mathrm{mg} / \mathrm{kg} \mathrm{mc} \text {. w } 50-100 \mathrm{ml} \text { 0,9-proc. } \\
\text { NaCl } 4 \text { h przed planowan chemioterapią, kontynuacja } \\
\text { nawet do } 7 \text { dni } \\
\text { Rozważyć opóźnienie chemioterapii w przypadku gdy } \\
\text { chory wymaga nawodnienia, poprawy czynności nerek } \\
\text { i wyrównania wskaźników biochemicznych }\end{array}$ \\
\hline Pośrednie & $\begin{array}{l}\text { Chłoniak Burkitta z LDH }<2 \times \text { ULN } \\
\text { ALL z WBC }<100 \mathrm{G} / \mathrm{l} \\
\text { AML z WBC }>10-50 \mathrm{G} / \mathrm{l} \\
\text { Chłoniaki o wysokim stopniu złośliwości } \\
\text { z LDH }<2 \times \text { ULN } \\
\text { Kryza blastyczna CML }\end{array}$ & $\begin{array}{l}\text { Płyny infuzyjne } 3 \mathrm{l} / \mathrm{m}^{2} / 24 \mathrm{~h} \text { (diureza godzinowa } \\
>80-100 \mathrm{ml} / \mathrm{m}^{2} \text { ); w przypadku niedostatecznej } \\
\text { diurezy diuretyk pętlowy } \\
\text { Allopurinol w dawce } 600 \mathrm{mg} / \mathrm{d} . \geq 24 \text { h przed } \\
\text { chemioterapią } \\
\text { Monitorowanie przed chemioterapią, zwłaszcza } \\
\text { w przypadkach niedostatecznej ilości płynów } \\
\text { przyjmowanych doustnie, skąpomoczu i wcześniejszego } \\
\text { uszkodzenia nerek } \\
\text { Stosowanie allopurinolu powinno być kontynuowany } \\
\text { przez okres pierwszego cyklu chemioterapii, a później } \\
\text { zależnie od obecności choroby bulky lub dny } \\
\text { moczanowej w wywiadzie }\end{array}$ \\
\hline Niskie & $\begin{array}{l}\text { AML z WBC < } 10 \mathrm{G} / \mathrm{l} \\
\text { Szpiczak plazmocytowy } \\
\text { Przewlekła białaczka limfocytowa } \\
\text { Indolentne chłoniaki } \\
\text { Chłoniak Hodgkina } \\
\text { Choroby mieloproliferacyjne }\end{array}$ & $\begin{array}{l}\text { Płyny doustnie } \\
\text { Allopurinol w dawce } 300 \mathrm{mg} / \mathrm{d} \text {. } \geq 24 \mathrm{~h} \text { przed } \\
\text { chemioterapią }\end{array}$ \\
\hline
\end{tabular}

LDH (lactate dehydrogenase) - dehrydrogenaza mleczanowa; ULN (upper limit normal) - powyżej normy; ALL (acute lymphoblastic leukemia) - ostra białaczka limfoblastyczna; WBC (white blood count) — liczba krwinek białych, AML (acute myeloid leukemia) - ostra białaczka szpikowa, NaCl — chlorek sodu; CML (acute myelogenous leukemia) — przewlekła białaczka szpikowa

nawet w nocy. U chorych ze znaczną hipoglikemią lub u których występują objawy kliniczne należy stosować dożylne infuzje glukozy lub glukagon podawany dożylnie albo podskórnie. W leczeniu wspomagającym można zastosować glukokortykoidy, zwłaszcza hydrokortyzon i prednizolon; oba leki zmniejszają stężenie big IGF-2. Diazoksyd, zwłaszcza w połączeniu $z$ diuretykiem tiazydowym, hamuje wydzielanie insuliny. Jednak jego stosowanie jest ograniczone, ponieważ obniża ciśnienie tętnicze. W sporadycznych przypadkach można podać analogi somatostatyny $[58,65,66]$.

Hiperglikemia w przebiegu nowotworowych chorób hematologicznych najczęściej wiąże się $z$ nasileniem insulinooporności u osób ze wspólistniejącą cukrzycą typu 2 lub ze zwiększonym zapotrzebowaniem na insulinę u pacjentów $z$ dotychczas prawidłowym stężeniem glukozy. Czynnikami, które sprzyjają występowaniu hiperglikemii, są: przedłużona steroidoterapia, niedobory odporności, przeciążenie żelazem w wyniku licznych przetoczeń koncentratów krwinek czerwonych, infekcje, zaburzona produkcja cytokin, żywienie pozajelitowe, wyniszczenie, sarkopenia. Hiperglikemia pogarsza wyniki leczenia u pacjentów $z$ chorobami onkohematologicznymi, nasilając inne zaburzenia metaboliczne (np. kwasicy), zwiększając ryzyko infekcji, niewydolności narządowych, toksyczności chemioterapii i ogólnie, zwiększając śmiertelność [2, 67].

Postępowanie $\mathrm{w}$ hiperglikemii u pacjentów $z$ nowotworami hematologicznymi nie różni się od leczenia innych stanów podwyższonego stężenia glukozy. W przypadkach ostrej ciężkiej hiperglikemii należy stosować intensywną insulinoterapię, płyny dożylnie oraz wyrównywać zaburzenia elektrolitowe i kwasowo-zasadowe. W przewlekłej hiperglikemii - cukrzycy typu 2 stosuje się insulinę lub doustne leki hipoglikemizujące [67]. 


\section{Hiperamonemia}

Hiperamonemia to zwiększone stężenie amoniaku w surowicy; u mężczyzn norma wynosi 27$-102 \mu \mathrm{g} / \mathrm{dl}(16-60 \mu \mathrm{mol} / \mathrm{l})$, u kobiet natomiast $19-87 \mu \mathrm{g} / \mathrm{dl}(11-51 \mu \mathrm{mol} / \mathrm{l})$. Jest to choroba metaboliczna związana z zaburzeniami cyklu mocznikowego prowadząca do encefalopatii. Początkowe bóle głowy, dezorientacja, splątanie, drżenie mięśni, nadmierna senność mogą przejść w śpiączkę, a niekiedy prowadzić do zgonu.

Wyróżnia się hiperamonemię pierwotną i wtórną. Przyczyną tej pierwszej jest mutacja genetyczna, która prowadzi do niedoboru enzymów biorących udział w przemianie amoniaku w mocznik w wątrobie. Natomiast przyczynami wtórnej hiperamonemii są najczęściej niewydolność wątroby, ostre lub przewlekłe choroby nerek, krwawienie do przewodu pokarmowego, nadmierne spożycie alkoholu, zmęczenie mięśni (wskutek niewydolności oddechowej lub drgawek) oraz zespoł Reye'a.

U pacjentów $z$ hematologicznymi chorobami nowotworowymi występuje najczęściej hiperamonemia idiopatyczna. Jest ona wynikiem stosowanej intensywnej chemioterapii albo zabiegu przeszczepienia szpiku kostnego $[68,69]$. Do cytostatyków, które mogą powodować niedobory lub dysfunkcje enzymów cyklu mocznikowego, należą cytarabina, daunomycyna, cyklofosfamid, etopozyd, winkrystyna, busulfan, asparaginaza, metotreksat, pochodne platyny, topotekan, melfalan, rytuksymab [70, 71]. Współistniejące wyniszczenie, sarkopenia, infekcje, zwłaszcza bakteriami wytwarzającymi ureazę, krwawienie $z$ przewodu pokarmowego czy żywienie pozajelitowe mogą nasilać hiperamonemię $[2,68]$.

Podstawę przewlekłego leczenia stanowi dieta niskobiałkowa i wysokokaloryczna. Zawartość białka w diecie nie powinna przekraczać $50 \mathrm{~g}$, dostarczając jedynie 6-10\% zapotrzebowania energetycznego. Choremu należy zapewnić odpowiednią liczbę i jakość kalorii przez dożylne podanie glukozy oraz lipidów, tak aby nie doprowadzić do wyniszczenia organizmu. Można stosować doustne mieszanki bezbiałkowe. W stanach ostrych, w przypadku wspólistniejących objawów neurologicznych, $\mathrm{u}$ chorych $\mathrm{z}$ wysokim stężeniem amoniaku należy zastosować leki obniżające stężenie mocznika fenylooctan lub benzoesan sodu (Ammonul ${ }^{\circledR}$ ), a w przypadkach opornych - fenylomaślan sodu (Ammonaps ${ }^{\circledR}$ ) lub glicerolu (Ravicti ${ }^{\circledR}$ ), kwas kargluminowy albo dializoterapię.

\section{Podsumowanie}

Zaburzenia metaboliczne i wodno-elektrolitowe występujące u pacjentów $z$ nowotworowymi chorobami hematologicznymi znacznie komplikują przebieg leczenia, a tym samym pogarszają jego skuteczność. Jako stany potencjalnie zagrażające życiu wymagają intensywnej terapii prowadzącej do wyrównania tych zaburzeń. Należy jednak pamiętać, że jeśli ich przyczyną jest choroba nowotworowa, to zastosowanie chemioterapii stanowi leczenie pierwszej linii i czasami jedyną szansę na opanowanie zaburzeń metabolicznych i elektrolitowych.

\section{Piśmiennictwo}

1. Spinazzé S, Schrijvers D. Metabolic emergencies. Crit Rev Oncol Hematol. 2006; 58(1): 79-89, doi: 10.1016/j.critrevonc.2005.04.004, indexed in Pubmed: 16337807.

2. Carella AM, Marinelli T, Di Pu, et al. Metabolic disorders in elderly patients with hematologic malignancies. World J Oncol Res. 2015; 2: 28-36.

3. Kokot F, Franek E. Zaburzenia gospodarki wodno-elektrolitowej i kwasowo-zasadowej. Wydawnictwo Lekarskie PZWL, Warszawa 2013.

4. Lewis II, Roberts KB. Zaburzenia gospodarki wodno-elektrolitowej. In: Beers MH, Porter RS, Jones TV, Kaplan JL, Berkwits M. ed. The Merck Manual podręcznik diagnostyki i terapii. Elsevier Urban\&Partner, Wrocław 2008: 1613.

5. Żak I. Równowaga wodno-elektrolitowa ustroju. In: Żak I. Chemia medyczna. ed. Śląska Akademia Medyczna, Katowice 2001: 80.

6. Cheuvront SN, Kenefick RW. Dehydration: physiology, assessment, and performance effects. Compr Physiol. 2014; 4(1): 257-285, doi: 10.1002/cphy.c130017, indexed in Pubmed: 24692140.

7. Huang LH, Ellsbury DL, George CS, Anchala KR. Dehydration: background, pathophysiology, epidemiology. http://emedicine. medscape.com/article/906999-overview (22.02.2018).

8. Gellert R. Signs and symptoms of dehydration in the elderly. Post Nauk Med. 2015; 28: 744-748.

9. Thomas DR, Cote TR, Lawhorne L, et al. Dehydration council. Understanding clinical dehydration and its treatment. J Am Med Dir Assoc. 2008; 9(5): 292-301, doi: 10.1016/j.jamda.2008.03.006, indexed in Pubmed: 18519109.

10. Braun MM, Barstow CH, Pyzocha NJ. Diagnosis and management of sodium disorders: hyponatremia and hypernatremia. Am Fam Physician. 2015; 91(5): 299-307, indexed in Pubmed: 25822386.

11. Spasovski G, Vanholder R, Allolio B, et al. Hyponatraemia Guideline Development Group. Clinical practice guideline on diagnosis and treatment of hyponatraemia. Eur J Endocrinol. 2014; 170(3): G1-47, doi: 10.1530/EJE-13-1020, indexed in Pubmed: 24569125.

12. Onitilo AA, Kio E, Doi SAR. Tumor-related hyponatremia. Clin Med Res. 2007; 5(4): 228-237, doi: 10.3121/cmr.2007.762, indexed in Pubmed: 18086907. 
13. Filippatos TD, Milionis HJ, Elisaf MS. Alterations in electrolyte equilibrium in patients with acute leukemia. Eur J Haematol. 2005; 75(6): 449-460, doi: 10.1111/j.1600-0609.2005.00547.x, indexed in Pubmed: 16313256.

14. Castillo JJ, Vincent M, Justice E. Diagnosis and management of hyponatremia in cancer patients. Oncologist. 2012; 17(6): 756-765, doi: 10.1634/theoncologist.2011-0400, indexed in Pubmed: 22618570.

15. Witek P. Postępy w rozpoznawaniu i leczeniu hiponatremii. Post Nauk Med. 2008; 2: 75-82.

16. Liamis G, Milionis H, Elisaf M. A review of drug-induced hyponatremia. Am J Kidney Dis. 2008; 52(1): 144-153, doi: 10.1053/j. ajkd.2008.03.004, indexed in Pubmed: 18468754.

17. Hamdi T, Latta S, Jallad B, et al. Cisplatin-induced renal salt wasting syndrome. South Med J. 2010; 103(8): 793-799, doi: 10.1097/ /SMJ.0b013e3181e63682, indexed in Pubmed: 20622742.

18. Momi J, Tang CM, Abcar AC, et al. Hyponatremia-what is cerebral salt wasting? Perm J. 2010; 14(2): 62-65, doi: 10.7812/tpp/08-066, indexed in Pubmed: 20740122.

19. Krzakowski M. Zespoły paranowotworowe. Pol Med Paliatywna. 2002; 1: 57-66.

20. Chamienia A. Gospodarka potasowa - podstawy teoretyczne i codzienna praktyka lekarska. Chor Serca Naczyń. 2004; 1: 97-107.

21. Rastegar A, Soleimani M. Hypokalaemia and hyperkalaemia. Postgrad Med J. 2001; 77(914): 759-764, doi: 10.1136/ /pgmj.77.914.759, indexed in Pubmed: 11723313.

22. Alfonzo AVM, Isles C, Geddes C, et al. Potassium disorders clinical spectrum and emergency management. Resuscitation. 2006; 70(1): 10-25, doi: 10.1016/j.resuscitation.2005.11.002, indexed in Pubmed: 16600469.

23. Perazella MA. Drug-induced hyperkalemia: old culprits and new offenders. Am J Med. 2000; 109(4): 307-314, doi: 10.1016/s00029343(00)00496-4, indexed in Pubmed: 10996582.

24. Kim HJ, Han SW, et al. Therapeutic approach to hyperkalemia. Nephron. 2002; 92 Suppl 1: 33-40, doi: 10.1159/000065375, indexed in Pubmed: 12401936.

25. Kamel KS, Wei C. Controversial issues in the treatment of hyperkalaemia. Nephrol Dial Transplant. 2003; 18(11): 2215-2218, doi: 10.1093/ndt/gfg323, indexed in Pubmed: 14551344.

26. Franek E, Kokot F. Hipokaliemia. Chor Serca Naczyń. 2006; 3: 203-206.

27. Cohn JN, Kowey PR, Whelton PK, et al. New guidelines for potassium replacement in clinical practice: a contemporary review by the National Council on Potassium in Clinical Practice. Arch Intern Med. 2000; 160(16): 2429-2436, doi: 10.1001/ /archinte.160.16.2429, indexed in Pubmed: 10979053.

28. Skinner R, Cotterill SJ, Stevens MC. Risk factors for nephrotoxicity after ifosfamide treatment in children: a UKCCSG Late Effects Group study. United Kingdom Children's Cancer Study Group. Br J Cancer. 2000; 82(10): 1636-1645, doi: 10.1054/ /bjoc.2000.1214, indexed in Pubmed: 10817497.

29. Muggia FM, Heinemann HO, Farhangi M, et al. Lysozymuria and renal tubular dysfunction in monocytic and myelomonocytic leukemia. Am J Med. 1969; 47(3): 351-366, doi: 10.1016/00029343(69)90219-8, indexed in Pubmed: 5258033.

30. Wulf GG, Jahns-Streubel G, Strutz F, et al. Paraneoplastic hypokalemia in acute myeloid leukemia: a case of renin activity in AML blast cells. Ann Hematol. 1996; 73(3): 139-141, doi: 10.1007/ /s002770050215, indexed in Pubmed: 8841102.

31. Gellert R. Hipo- i hiperkalcemia — patogeneza i problemy terapeutyczne. Forum Nefrol. 2011; 4: 373-382.
32. Pawlak WZ, Wawrocka-Pawlak M. Hiperkalcemia w chorobie nowotworowej - patofizjologia, diagnostyka, leczenie. Współcz Onkol. 2003; 7: 482-496.

33. Carroll MF, Schade DS. A practical approach to hypercalcemia. Am Fam Physician. 2003; 67(9): 1959-1966, indexed in Pubmed: 12751658.

34. Nanji AA. Misleading biochemical laboratory test results. Can Med Assoc J. 1984; 130(11): 1435-1441, indexed in Pubmed: 6375845.

35. Vassilopoulou-Sellin R, Newman B, Taylor S, et al. Incidence of hypercalcemia in patients with malignancy referred to a comprehensive cancer center. Cancer. 1993; 71(4): 1309-1312, doi: 10.1002/1097-0142(19930215)71:4<1309::aid-cncr2820710423> 3.0.co;2-m, indexed in Pubmed: 8382106.

36. Nosaka K, Miyamoto T, Sakai T, et al. Mechanism of hypercalcemia in adult T-cell leukemia: overexpression of receptor activator of nuclear factor kappaB ligand on adult T-cell leukemia cells. Blood. 2002; 99(2): 634-640, doi: 10.1182/blood.v99.2.634, indexed in Pubmed: 11781248.

37. Majumdar G. Incidence and prognostic significance of hypercalcaemia in B-cell non-Hodgkin's lymphoma. J Clin Pathol. 2002; 55(8): 637-638, doi: 10.1136/jcp.55.8.637-a, indexed in Pubmed: 12147666.

38. Littlewood TJ, Lydon AP, Barton CJ. Hypercalcemia and osteolytic lesions associated with chronic lymphatic leukemia (CLL). J Clin Pathol. 1990; 43(10): 877, doi: 10.1136/jcp.43.10.877-a, indexed in Pubmed: 2229443.

39. Kent AB, Weinstein RS. Case report: hypercalcemia in acute myeloblastic leukemia is caused by osteoclast activation. Am J Med Sci. 1993; 306(3): 169-173, doi: 10.1097/00000441-19930900000008, indexed in Pubmed: 8128979.

40. Sharma N, Jain S, Kumari S, et al. Hypercalcaemia with radiographic abnormalities in chronic myeloid leukaemia. Postgrad Med J. 1998; 74(871): 301-303, doi: 10.1136/pgmj.74.871.301, indexed in Pubmed: 9713619

41. Trehan A, Cheetham T, Bailey S. Hypercalcemia in acute lymphoblastic leukemia: an overview. J Pediatr Hematol Oncol. 2009; 31(6): 424-427, doi: 10.1097/MPH.0b013e3181a1c12b, indexed in Pubmed: 19648791.

42. Smarz-Widelska I, Syroka-Główka M, Książek P, et al. Hiperkalcemia w wybranych przypadkach klinicznych. Nefrol Dial Pol. 2006; 10: 34-37.

43. Jakubas-Kwiatkowska W, Błachowicz A, Franek E. Hipokalcemia w praktyce klinicznej — przyczyny, objawy i leczenie. Chor Serca Naczyń. 2005; 2: 232-237.

44. Londner M. Gospodarka kwasowo-zasadowa i jej zaburzenia. In: Beers MH, Porter RS, Jones TV, Kaplan JL, Berkwits M. ed. The Merck Manual podręcznik diagnostyki i terapii. Elsevier Urban\&Partner, Wrocław 2008: 1650.

45. Żak I. Równowaga kwasowo-zasadowa ustroju. In: Żak I. ed. Chemia Medyczna. Śląska Akademia Medyczna, Katowice 2001: 122.

46. Sacks GS. The ABC's of acid-base balance. J Pediatr Pharmacol Ther. 2004; 9(4): 235-242, doi: 10.5863/1551-6776-9.4.235, indexed in Pubmed: 23118702.

47. Kokot F, Franek E. Zaburzenia równowagi kwasowo-zasadowej. In: Szczeklik A. ed. Choroby wewnętrzne. Medycyna Praktyczna, Kraków 2011: 2302.

48. Claudino WM, Dias A, Tse W, et al. Type B lactic acidosis: a rare but life threatening hematologic emergency. A case illustration and brief review. Am J Blood Res. 2015; 5(1): 25-29, indexed in Pubmed: 26171281.

49. Cairo MS, Bishop M. Tumour lysis syndrome: new therapeutic strategies and classification. Br J Haematol. 2004; 127(1): 
3-11, doi: 10.1111/j.1365-2141.2004.05094.x, indexed in Pubmed: 15384972.

50. Mirrakhimov AE, Voore P, Khan M, et al. Tumor lysis syndrome: a clinical review. World J Crit Care Med. 2015; 4(2): 130-138, doi: 10.5492/wjccm.v4.i2.130, indexed in Pubmed: 25938028.

51. Montesinos P, Lorenzo I, Martín G, et al. Tumor lysis syndrome in patients with acute myeloid leukemia: identification of risk factors and development of a predictive model. Haematologica. 2008; 93(1): 67-74, doi: 10.3324/haematol.11575, indexed in Pubmed: 18166787.

52. Jones GL, Will A, Jackson GH, et al. British Committee for Standards in Haematology. Guidelines for the management of tumour lysis syndrome in adults and children with haematological malignancies on behalf of the British Committee for Standards in Haematology. Br J Haematol. 2015; 169(5): 661-671, doi: 10.1111/ /bjh.13403, indexed in Pubmed: 25876990.

53. Coiffier B, Altman A, Pui CH, et al. Guidelines for the management of pediatric and adult tumor lysis syndrome: an evidence-based review. J Clin Oncol. 2008; 26(16): 2767-2778, doi: 10.1200/ /JC0.2007.15.0177, indexed in Pubmed: 18509186.

54. Malberti F. Hyperphosphataemia: treatment options. Drugs. 2013; 73(7): 673-688, doi: 10.1007/s40265-013-0054-y, indexed in Pubmed: 23625273.

55. Nayar M, Lombard M, Furlong N, et al. Diagnosis and management of nonislet cell tumor hypoglycemia. Endocrinologist. 2006; 16(4): 227-230, doi: 10.1097/01.ten.0000226008.02412.0b.

56. Halsall DJ, Mangi M, Soos M, et al. Hypoglycemia due to an insulin binding antibody in a patient with an IgA-kappa myeloma. J Clin Endocrinol Metab. 2007; 92(6): 2013-2016, doi: 10.1210/ /jc.2007-0075, indexed in Pubmed: 17405845.

57. Hoogwerf D, van Doorn J, Maartense E. The insulin-like growth factor-system in a patient with diffuse large B-cell non-Hodgkin's lymphoma and lactic acidosis. Ann Clin Biochem. 2013; 50(Pt 2): 169-172, doi: 10.1258/acb.2012.012125, indexed in Pubmed: 23467067

58. Iglesias P, Díez JJ. Management of endocrine disease: a clinical update on tumor-induced hypoglycemia. Eur J Endocrinol. 2014; 170(4): R147-R157, doi: 10.1530/EJE-13-1012, indexed in Pubmed: 24459236

59. Hussain BM, Geetha N, Lali V, et al. Rituximab induced hypoglycemia in non-Hodgkin's lymphoma. World J Surg Oncol. 2006; 4: 89, doi: 10.1186/1477-7819-4-89, indexed in Pubmed: 17156470.

60. Agostino NM, Chinchilli VM, Lynch CJ, et al. Effect of the tyrosine kinase inhibitors (sunitinib, sorafenib, dasatinib, and imatinib) on blood glucose levels in diabetic and nondiabetic patients in ge- neral clinical practice. J Oncol Pharm Pract. 2011; 17(3): 197-202, doi: 10.1177/1078155210378913, indexed in Pubmed: 20685771.

61. Bay A, Oner AF, Cesur Y, et al. Symptomatic hypoglycemia: an unusual side effect of oral purine analogues for treatment of ALL. Pediatr Blood Cancer. 2006; 47(3): 330-331, doi: 10.1002/ /pbc.20582, indexed in Pubmed: 16047348.

62. Nunnari G, Celesia BM, Bellissimo F, et al. Trimethoprim-sulfamethoxazole-associated severe hypoglycaemia: a sulfonylurea-like effect. Eur Rev Med Pharmacol Sci. 2010; 14(12): 1015-1018, indexed in Pubmed: 21375132.

63. Parra-Riffo H, Lemus-Peñaloza J. Severe levofloxacin-induced hypoglycaemia: a case report and literature review. Nefrologia. 2012; 32(4): 546-547, doi: 10.3265/Nefrologia.pre2012.Feb.11248, indexed in Pubmed: 22806298.

64. Pelosof LC, Gerber DE. Paraneoplastic syndromes: an approach to diagnosis and treatment. Mayo Clin Proc. 2010; 85(9): 838-854, doi: 10.4065/mcp.2010.0099, indexed in Pubmed: 20810794.

65. Davda R, Seddon BM. Mechanisms and management of non-islet cell tumour hypoglycaemia in gastrointestinal stromal tumour: case report and a review of published studies. Clin Oncol (R Coll Radiol). 2007; 19(4): 265-268, doi: 10.1016/j.clon.2006.12.008, indexed in Pubmed: 17433971.

66. Bodnar TW, Acevedo MJ, Pietropaolo M. Management of non-islet-cell tumor hypoglycemia: a clinical review. J Clin Endocrinol Metab. 2014; 99(3): 713-722, doi: 10.1210/jc.2013-3382, indexed in Pubmed: 24423303.

67. Healy SJ, Dungan KM. Hyperglycemia in patients with hematologic malignancies. Curr Diab Rep. 2015; 15(3): 8, doi: 10.1007/ /s11892-015-0581-x, indexed in Pubmed: 25644817.

68. Fine P, Adler K, Gerstenfeld D. Idiopathic hyperammonemia after high-dose chemotherapy. Am J Med. 1989; 86(5): 629, indexed in Pubmed: 2712077.

69. Ho AY, Mijovic A, Pagliuca A, et al. Idiopathic hyperammonaemia syndrome following allogeneic peripheral blood progenitor cell transplantation (allo-PBPCT). Bone Marrow Transplant. 1997; 20(11): 1007-1008, doi: 10.1038/sj.bmt.1701003, indexed in Pubmed: 9422485.

70. Chen YH, Chiou TJ, Hsu YN, et al. Idiopathic hyperammonemia after chemotherapy with vinorelbine, topotecan, and cisplatin in a patient with acute lymphocytic leukemia. Hematol Oncol Stem Cell Ther. 2010; 3(4): 199-202, doi: 10.5144/1658-3876.2010.199, indexed in Pubmed: 21150241.

71. Nott L, Price TJ, Pittman K, et al. Hyperammonaemic encephalopathy associated with rituximab-containing chemotherapy. Intern Med J. 2008; 38(10): 800-803, doi: 10.1111/j.14455994.2008.01772.x, indexed in Pubmed: 19143880. 